\title{
Statyba
}

\section{APPLICATION OF METHOD OF MULTIPLE CRITERIA ANALYSIS FOR ESTABLISHING VALUE}

\section{Malienè , A. Kaklauskas \& E. K. Zavadskas}

To cite this article: V. Malienè , A. Kaklauskas \& E. K. Zavadskas (2000) APPLICATION OF METHOD OF MULTIPLE CRITERIA ANALYSIS FOR ESTABLISHING VALUE, Statyba, 6:5, 295-306, DOI: $10.1080 / 13921525.2000 .10531606$

To link to this article: https://doi.org/10.1080/13921525.2000.10531606

$$
\text { 曲 Published online: } 26 \text { Jul } 2012 .
$$

Submit your article to this journal $\pi$

ЏII Article views: 85 


\title{
DAUGIAKRITERINĖS NEKILNOJAMOJO TURTO ANALIZÉS VERTÉS NUSTATYMO METODAS IR JO TAIKYMAS
}

\author{
V. Malienė, A. Kaklauskas, E. K. Zavadskas \\ Vilniaus Gedimino technikos universitetas
}

\section{Ivadas}

Nekilnojamasis turtas (žemė, statiniai ir ju priklausiniai) yra patikima investicija, prekè, turtinis garantas, kiekvieno piliečio būstas, darbo ar poilsio vieta, verslo ar veiklos priemoné, pragyvenimo šaltinis ir kt. Todèl natūralu, kad nekilnojamuoju turtu suinteresuoty grupiụ yra daug ir ivairiu (pardavejai, pirkèjai, kreditoriai, agentai, investuotojai, vertintojai, valstybè ir t. t.) ir visos jos turi asmeninių poreikių ir siekiamų tikslų. Šiems suinteresuotu grupiu tikslams igyvendinti (investuoti $i$ nekilnojamaji turta, ji pirkti ir parduoti, ikeisti ar pasirinkti) atsižvelgiant $\mathfrak{i}$ jų poreikius taikomos tam tikros procedūru, susijusiu su nekilnojamuoju turtu, vykdymo taisykles ir kontrolę reglamentuojančios priemonès - atliekama nekilnojamojo turto analizè ir jo vertinimas ivairiais aspektais.

XX ir XXI amžiu sandūroje tarptautineje nekilnojamojo turto analizès ir vertinimo praktikoje vyksta reikšmingos permainos, kurioms turi itakos besikeičiančios ekonominès ir socialinès sąlygos, teisiniai santykiai visuomenėje. Kainų pokyčiai ir ekonominis pagristumas vertinant nekilnojamaji turtą igyja išskirtinę reikšmę. Kartu didejja visuomenès ir pavienių asmenų poreikis vertę nustatyti tiksliai ir patikimai.

Iki šiol taikytus klasikinius nekilnojamojo turto vertès nustatymo metodus ne visuomet pavyksta apibrèžti matematiškai, patenkinant suinteresuotu grupių - pirkèju, pardavejju, investuotojų ir kt. tikslus ir interesus. Vis dažniau vertintojas susiduria su tokiais nekilnojamojo turto vertès nustatymo klausimais, kurie negali būti išspręsti klasikiniais vertinimo metodais. Vertintojo veiklą sunkina ir tai, kad užsakovas reikalauja kuo tikslesnès ir lengvai suprantamos nekilnojamojo turto analizès ir jo vertinimo populiariais metodais. Be to, neklasikinių nekilnojamojo turto analizès ir vertinimo metodu taikymas yra teisiškai nepagristas. Todel dažnai vertintojas priverstas rinktis tokius sprendimo būdus, kurie matematiškai aprašomi tik sąlygiškai. Tokiais atvejais vertintojo veiksmai yra subjektyvūs, jo taikomas nekilnojamojo turto vertinimo metodas - nepatikimas. Tačiau, kaip žinoma, nustatant nekilnojamojo turto verte, svarbiausia yra vertinimo metodo objektyvumas ir patikimumas. Todèl vertess nustatymo metodologijoje atsirado būtinybè daryti pakeitimus.

Nekilnojamojo turto vertinimui yra svarbi ne tik paties nekilnojamojo turto vertès nustatymo metodo matematinè struktūra bei jo taikymo galimybès, bet taip pat labai svarbus ir visụ be išimties nekilnojamojo turto vertę veikiančių kriteriju - objekto kokybiniu (vietovès infrastruktūra, turto fizinès savybès, vietos padètis, teisiniai veiklos apribojimai ir t.t.) ir kiekybiniu (turto plotas, pastatu skaičius žemés sklype, tūris, aukštu skaičius, statybos metai ir t. t.) charakteristiku, rinkos konjunktūros (nekilnojamojo turto paklausa ir pasiūla, investiciju palankumas, vietovès ekonominè ir demografinè struktūros) ir kt. - nuoseklus suvokimas. Išsamus vertę veikiančių veiksnių apibūdinimas priartina prie realiausios siekiamos nustatyti nekilnojamojo turto vertès. Kiekvienai skirtingos paskirties ir rūšies nekilnojamojo turto vertei itaką darančius veiksnius lemia ekonominiai, teisiniai, socialiniai, politiniai, valstybès planavimo ir psichologiniai kriterijai [1], kuriu vertinimas priklauso ne tik nuo vertintojo ižvalgumo bei profesionalumo, bet ir nuo vertinimo metodu pajégumo analizuoti minètus kriterijus.

Daugeli problemu, su kuriomis susiduriama vertinant nekilnojamaji turtą, galima išspresti daugiakriterinès analizès metodais $[2,3]$. Šiame straipsnyje pateiktas daugiakriterinès nekilnojamojo turto analizès vertès nustatymo metodas. Šio metodo privalumai yra šie: 
- Šj metodą gali taikyti visos nekilnojamuoju turtu suinteresuotos grupés - rinkos dalyviai: pirkejjai, pardavejai, investuotojai, vertintojai ir kt., - siekiančios patenkinti savo poreikius ir tikslus. Investuotojas gali vertinti turtą geriausio ir naudingiausio naudojimo aspektu, nekilnojamojo turto vertintojas - rinkos situacijos aspektu, pirkejjas - maksimalaus savo asmeninių poreikių tenkinimo aspektu ir pan. Vertinant turtą skirtingais požiūriais, skiriasi vertei ịtaką darantys veiksniai, kuriụ kiekis ir reikšmingumas taikant šị metodą gali būti lengvai keičiami.

- Siūlomas daugiakriterinès analizès vertès nustatymo metodas yra vienas iš nekilnojamojo turto vertinimo metodų, leidžiančių nustatyti ne tik nekilnojamojo turto rinkos vertę, bet ir kitas nekilnojamojo turto vertes. Taikant ši metodą atliekama ir kompleksiné turto analizé - nustatomas objektų naudingumas ir prioritetiškumas vienas kito atžvilgiu, taip pat veiksnių, lemiančiụ nekilnojamojo turto vertę, reikšmingumai bei nagrinèjamų objektų konkurencingumas.

- Daugiakriterinès analizès vertès nustatymo metodas gali būti taikomas kaip savarankiškas vertès nustatymo metodas ir klasikinių metodų dalis: taikant lyginamosios vertès metodą - atskiriems kriterijams (pvz., rajono infrastruktūrai, vertinamojo turto vietos padèčiai ir t. t. nustatyti), veikiantiems nekilnojamojo turto rinkos vertę, ivertinti; taikant atkuriamosios vertès metodą - pastato nusidèvèjimui ìvertinti.

Daugiakriterinès analizès vertès nustatymo metodas paremtas rinkos ir nekilnojamojo turto analize bei nekilnojamojo turto objektu vertę veikiančiu kokybinių, kiekybinių bei rinkos konjunktūros kriterijų nustatymu ir ivertinimu. Todèl šis metodas leidžia kompleksiškai vertinti ne tik lyginamuju turto objektu kokybinius, bet ir kiekybinius bei su tais objektais susijusių rinkų konjunktūrų skirtumus.

\section{Daugiakriterinei analizei reikalingụ pradinių duo- menų rengimas}

Nekilnojamojo turto daugiakriterinei analizei atlikti būtina parengti sprendimų prièmimo matricą, kuri sudaroma šiais etapais:

- surenkama informacija apie nagrinejjamus objektus;

- nustatomi kriterijai, apibūdinantys suinteresuotụ grupių tikslus;
- nustatomi objektą apibūdinančių kriterijų matavimo vienetai, reikšmès ir reikšmingumai;

- grupuojant kriterijus, jų reikšmes ir reikšmingumus sudaroma sugrupuota sprendimų prièmimo matrica.

Nekilnojamojo turto daugiakriterinei analizei atlikti būtina apie nagrinejjamus nekilnojamojo turto objektus surinkti informaciją, apibūdinančią kiekybines ir kokybines objektu charakteristikas. Jeigu nagrinejjami objektai yra iš skirtingu rinku ir nekilnojamojo turto daugiakriterinès analizès tikslas yra nustatyti rinkos vertę, tuomet būtina surinkti informaciją, apibūdinančią nagrinejjamų objektụ rinkos konjunktūras (nekilnojamojo turto pasiūlą ir paklausą vietoveje). Visa informacija, apibūdinanti objektus, aprašoma kiekybine ir koncepcine formomis. Taip aprašant nekilnojamojo turto objektus pateikiami jivairūs ju aspektai (ekonominiai, techniniai, technologiniai, infrastruktūriniai, kokybiniai (architektūriniai, estetiniai, komfortiniai), teisiniai, socialiniai ir t. t.).

Kriteriju sistema, apibūdinanti nagrinejjamus nekilnojamojo turto objektus, sudaroma remiantis suinteresuotu grupių siekiamais tikslais. Rinkos ir kitas vertes apibūdinančias sistemas sudaro kriterijai, veikiantys rinkos ar kitas nekilnojamojo turto vertes. Šiems tikslams igyvendinti kriteriju sistemos sudaromos remiantis nekilnojamojo turto rinkos analize, tarptautine moksline literatūra bei ekspertų nuomone. Patenkinant kitus suinteresuotu grupių tikslus, sudaromos kriterijų sistemos, apibūdinančios asmeninių poreikių prioritetus.

Vienas svarbiausiu nekilnojamojo turto daugiakriterinès analizès etapu - nekilnojamojo turto objektus apibūdinančių kriterijụ reikšmiụ ir reikšmingumų nustatymas. Kriterijų, apibūdinančių nagrinèjamu objektu kiekybę ir kokybę, reikšmingumai bei alternatyvų kokybiniu kriterijų reikšmés dažniausiai apskaičiuojami ekspertiniais metodais [4-6]. Taikant ekspertinius metodus, nustatomoms kokybinių kriterijụ reikšmèms gali būti suteiktas tam tikras balų skaičius. Kriterijai jvertinami pagal didejjančią arba mažèjančią vertinimo skalę.

Norint proporcingai ịvertinti kokybinių kriterijų reikšmes, ekspertinis vertinimas atliekamas lyginimo būdu. Šiuo atveju kokybiniụ kriterijụ reikšmès nustatomos taip [7]:

* išrenkama geriausia kriterijaus reikšme $\mathrm{x}_{\mathrm{ger}}$;

* geriausia nagrinèjamo kriterijaus reikšmé ivertinama 1 balu $\left(\mathrm{x}_{\text {ger }}=1\right)$;

* nustatoma, kiek procentu $\left(\mathrm{p}_{\mathrm{i}}\right)$ likusios to paties 
kriterijaus reikšmès $\left(\mathrm{x}_{1}\right)$ yra blogesnès už geriausią $\left(\mathrm{x}_{\text {ger }}=1\right)$;

* likusioms kriterijaus reikšmėms suteikiamos santykinès reikšmès $\left(x_{i}=1-p_{i}: 100\right)$;

* visų kriteriju santykinès reikšmès perskaičiuojamos taip, kad jụ suma būtų lygi vienetui.

Analogiškai nustatomi ir kriterijų pradiniai reikšmingumai. Nekilnojamojo turto objekto rinkos kaina priklauso nuo jo kiekybès, kokybès ir rinkos konjunktūros, todèl nagrinejjamų objektų rinkos kainos kriterijaus reikšmingumas lygus visų kitų kriterijų reikšmingumu sumai, kuri gali būti lygi 1 balui, arba $100 \%$, o kitu kriterijų reikšmingumai nustatomi ekspertiniu būdu.

Norint atlikti nekilnojamojo turto daugiakriterinę analizę, būtina sudaryti sprendimų prièmimo matricą. Tai atliekama analizuojant koncepcinę informaciją apie nagrinėjamus objektus, nustatant objektų kriterijų reikšmes ir reikšmingumus. Apskaičiavus kriterijų reikšmes ir reikšmingumus bei taikant nekilnojamojo turto daugiakriterinès analizès metodus, galima nustatyti lygina- muju objektų variantụ prioritetiškumą, naudingumą bei vertes.

Atliekant daugiakriterinę nekilnojamojo turto analizę, nagrinèjamus nekilnojamojo turto objektus apibūdinanti informacija apdorojama matriciniu būdu. 1 lenteleje pateikiama nagrinèjamų objektų daugiakriterinès analizès sugrupuota sprendimı prièmimo matrica, kur stulpeliuose pateikiami nagrinejjami $n$ objektai, o eilutèse pateikiama jų kiekybinè ir koncepcinè informacija, išsamiai apibūdinanti nagrinejjamus objektus. Šiuos objektus aprašant kiekybine ir koncepcine formomis, pateikiama ivairius ju aspektus: ekonominius, techninius, technologinius, infrastruktūrinius, kokybinius (architektūrinius, estetinius, komfortinius), teisinius bei socialinius - apibūdinanti informacija. Kiekybinè informacija apima kriterijų sistemas, matavimo vienetus, reikšmes ir pradinius reikšmingumus, minimizuojanti ar maksimizuojanti kriterijų, informaciją apie nagrinejjamų objektų variantų sudarymą.

1 lentelè. Nagrinèjamų objektų daugiakriterinès analizès sugrupuota sprendimų prièmimo matrica

Table 1. A grouped decision-making matrix of multiple criteria analysis applied to the objects considered

\begin{tabular}{|c|c|c|c|c|c|c|c|c|c|}
\hline \multicolumn{10}{|c|}{ Objektus apibūdinanti kiekybinė informacija } \\
\hline \multirow{2}{*}{ Nagrinèjami kriterijai } & & \multirow{2}{*}{$\begin{array}{c}\text { Reikšmin- } \\
\text { gumas }\end{array}$} & \multirow{2}{*}{$\begin{array}{c}\text { Matavimo } \\
\text { vienetai }\end{array}$} & \multicolumn{6}{|c|}{ Nagrinèjami objektai } \\
\hline & & & & 1 & 2 & $\ldots$ & $\mathrm{j}$ & $\ldots$ & $\mathrm{n}$ \\
\hline \multirow{6}{*}{ Kiekybiniai kriterijai } & $\check{z}_{1}$ & $\mathrm{q}_{1}$ & $m_{1}$ & $\mathrm{x}_{11}$ & $x_{12}$ & $\cdots$ & $\mathbf{x}_{1 j}$ & $\ldots$ & $x_{\ln }$ \\
\hline & $\check{z}_{2}$ & $\mathrm{q}_{2}$ & $m_{2}$ & $\mathbf{x}_{21}$ & $\mathrm{x}_{22}$ & $\cdots$ & $\mathrm{x}_{2 \mathrm{j}}$ & $\cdots$ & $x_{2 n}$ \\
\hline & $\cdots$ & $\cdots$ & $\ldots$ & $\ldots$ & $\ldots$ & $\ldots$ & $\ldots$ & $\ldots$ & $\ldots$ \\
\hline & $\check{z}_{i}$ & $q_{i}$ & $\mathrm{~m}_{\mathrm{i}}$ & $\mathrm{x}_{\mathrm{i} 1}$ & $\mathrm{x}_{\mathrm{i} 2}$ & $\cdots$ & $\mathrm{x}_{\mathrm{ij}}$ & $\cdots$ & $x_{\text {in }}$ \\
\hline & $\cdots$ & $\cdots$ & $\cdots$ & $\cdots$ & $\cdots$ & $\cdots$ & $\cdots$ & $\cdots$ & $\cdots$ \\
\hline & $\check{z}_{1}$ & $q_{1}$ & $m_{t}$ & $x_{t 1}$ & $x_{12}$ & $\ldots$ & $x_{i j}$ & $\ldots$ & $x_{\text {tn }}$ \\
\hline \multirow{6}{*}{ Kokybiniai kriterijai } & $\check{z}_{1+1}$ & $q_{t+1}$ & $m_{t+1}$ & $x_{t+1 t}$ & $x_{t+1}=$ & $\ldots$ & $x_{t+1 j}$ & $\ldots$ & $x_{t+1 n}$ \\
\hline & $\check{z}_{t+2}$ & $q_{1+2}$ & $m_{t+2}$ & $x_{t+21}$ & $x_{1+22}$ & $\cdots$ & $x_{1+2 j}$ & $\ldots$ & $x_{t+2 n}$ \\
\hline & $\cdots$ & $\cdots$ & $\ldots$ & $\ldots$ & $\ldots$ & $\ldots$ & $\ldots$ & $\ldots$ & $\cdots$ \\
\hline & $\check{z}_{i}$ & $\mathrm{q}_{\mathrm{i}}$ & $\mathrm{m}_{\mathrm{i}}$ & $\mathbf{x i}_{1}$ & $x_{i_{2}}$ & $\cdots$ & $\mathrm{x}_{\mathrm{ij}}$ & $\cdots$ & $x_{\text {in }}$ \\
\hline & $\cdots$ & $\cdots$ & $\cdots$ & $\cdots$ & $\cdots$ & $\cdots$ & $\cdots$ & $\cdots$ & $\cdots$ \\
\hline & $\check{Z}_{\mathrm{m}}$ & $q_{m}$ & $\mathrm{~m}_{\mathrm{m}}$ & $\mathrm{x}_{\mathrm{ml}}$ & $x_{m:}$ & $\ldots$ & $\mathrm{x}_{\mathrm{mj}}$ & $\ldots$ & $x_{m n}$ \\
\hline \multicolumn{10}{|c|}{ Objektus apibūdinanti koncepcinè informacija (tekstas, brēžiniai, grafikai, vaizdajuostès) } \\
\hline $\mathrm{K}_{\mathrm{k}}$ & $\mathrm{K}_{\dot{i}}$ & $\mathrm{~K}_{4}$ & $\mathrm{~K}_{\mathrm{m}}$ & $\mathbf{K}_{1}$ & $\mathrm{~K}_{2}$ & $\ldots$ & $\mathrm{K}_{\mathrm{i}}$ & $\ldots$ & $\mathrm{K}_{\mathrm{n}}$ \\
\hline
\end{tabular}

Ženklas $\check{z}_{\mathrm{i}}(+(-))$ rodo, kad atitinkamai didesnè (mažesnè) kriterijaus reikšmé labiau atitinka suinteresuotos grupés reikalavimus. 
Nagrinejjamus objektus aprašant koncepcine forma: tekstu, schemomis, grafikais, diagramomis, brèžiniais ir vaizdajuostemis, - pateikiama koncepcinè informacija apie pačius objektus ir juos išsamiai apibūdinančius kriterijus (ju aprašymas, priežastys ir pagrindimas, kuriais remiantis buvo nustatyti kriteriju sistema, reikšmès ir reikšmingumai). Koncepcine informacija padeda išsamiau ir tiksliau jvertinti nagrinejjamus objektus, t. y. ji ne tik padeda gauti išsamesnę informaciją, bet ir tiksliau sudaryti kriteriju sistemą, nustatyti kriteriju reikšmes ir reikšmingumus.

Sugrupuotoje sprendimụ prièmimo matricoje kriterijai grupuojami i dvi grupes: i kiekybinius ir kokybinius kriterijus, prireikus ir $\mathfrak{i}$ trečią grupe - rinkos konjunktūros kriterijus. Taip lengviau atlikti nekilnojamojo turto daugiakriterinę analizę, taip pat geriau matoma skaičiavimụ fizinè prasmè. Nekilnojamojo turto daugiakriterinès analizès metu dažniausiai operuojama gausia informacija, todèl ją racionalu apdoroti matriciniu būdu. Šiuo atveju nagrinèjami nekilnojamojo turto objektai, juos apibūdinanti kiekybinè ir koncepcinè informacija grupuojami tam tikra tvarka, t. y. sudaroma nagrinèjamų objektų daugiakriterinès analizès sugrupuota sprendimų prièmimo matrica.

\section{Daugiakriterinès nekilnojamojo turto analizès ver- tès nustatymo metodas}

Daugiakriterinès nekilnojamojo turto analizés vertès nustatymo metodas atliekamas pagal 1 paveiksle pateiktą metodo struktūrinę schemą.

Vertinamojo objekto vertè nustatoma artẹjimo būdu per kelis ir daugiau metodo artèjimo ciklus, kol vertinamojo objekto $a_{x}$ naudingumo lygio $N_{j}$ vidutinis nuokrypis $k_{x}$ atitinka sąlygą $\left|k_{a x}\right|<1 \%$.

Daugiakriterinès nekilnojamojo turto analizès vertès nustatymo metodas pateiktas struktūrinejje schemoje. Ji sudaro dvylika etapų, iš jų du yra pradinių duomenu rinkimo ir tvarkymo etapai.

1 etapas. Kriterijų, darančiu ịtaką nekilnojamojo turto objekty vertei, sistemos sudarymas.

2 etapas. Kriteriju matavimo vienetú, reikšmiụ ir pradinių reikšmingumų nustatymas (žr. pav.).

3 etapas. Sudaroma normuotoji sprendimų prièmimo matrica D. Šio etapo tikslas - iš lyginamụ rodikliụ gauti bedimensius ivertintus dydžius. Kai jie žinomi, visus skirtingų matavimo vienetų rodiklius galima palyginti pagal šią formulę:

$$
d_{i j}=\frac{x_{i j} \cdot q_{i}}{\sum_{j=1}^{n} x_{i j}}, \quad i=\overline{1, m}, \quad j=\overline{1, n} .
$$

Kiekvieno kriterijaus $x_{i}$ gautų bedimensių jvertintų reikšmių $d_{i j}$ suma visada lygi šio kriterijaus reikšmingumui $q_{i}$ :

$$
q_{i j}=\sum_{j=1}^{n} d_{i j}, \quad i=\overline{1, m}, \quad j=\overline{1, n} .
$$

4 etapas. Apskaičiuojamos j variantą apibūdinančių minimizuojančių $S_{-j}$ ir maksimizuojančiu $S_{+j}$ ivertintụ normalizuotų rodikliụ sumos pagal formulę:

$$
S_{+j}=\sum_{i=1}^{m} d_{+i j}, S_{-j}=\sum_{i=1}^{m} d_{-i j}, i=\overline{1, m}, j=\overline{1, n}
$$

Šiuo atveju $S_{+j}$ ir $S_{-j}$ dydžiai išreiškia lyginamaisiais objektais pasiektų tikslų lygi.

Bet kuriuo atveju visų lyginamuju objektų pliusų $S_{+j}$ ir minusu $S_{-j}$ sumos visada yra atitinkamai lygios visoms maksimizuojančių ir minimizuojančių kriterijų reikšmingumų sumoms:

$$
\begin{gathered}
S_{+j}=\sum_{j=1}^{n} S_{+j}=\sum_{i=1}^{m} \sum_{j=1}^{n} d_{+i j}, \\
S_{-j}=\sum_{j=1}^{n} S_{-j}=\sum_{i=1}^{m} \sum_{j=1}^{n} d_{-i j}, \\
i=\overline{1, m}, \quad j=\overline{1, n} .
\end{gathered}
$$

5 etapas. Lyginamuju objektų santykinis reikšmingumas (efektyvumas) nustatomas remiantis juos apibūdinančiomis teigiamomis $\left(_{+} S_{+j}\right.$ ir neigiamomis (-) $S_{-j}$ savybèmis. Kiekvieno varianto $a_{j}$ santykinis reikšmingumas $Q_{j}$ nustatomas pagal formulę:

$$
Q_{j}=S_{+j}+\frac{S_{-\min } \cdot \sum_{j=1}^{n} S_{-j}}{S_{-j} \cdot \sum_{j=1}^{n} \frac{S_{-\min }}{S_{-j}}}, j=\overline{1, n}
$$

6 etapas. Nustatomas objektu prioritetiškumas. Juo didesnis $Q_{j}$, tuo didesnis varianto efektyvumas (prioritetiškumas). Apibendrintas kriterijus $Q_{j}$ tiesiogiai ir proporcingai priklauso nuo lyginamuju kriteriju reikšmiu $x_{i j}$ ir reikšmingumu $q_{i}$ santykinès itakos galutiniam rezultatui. 


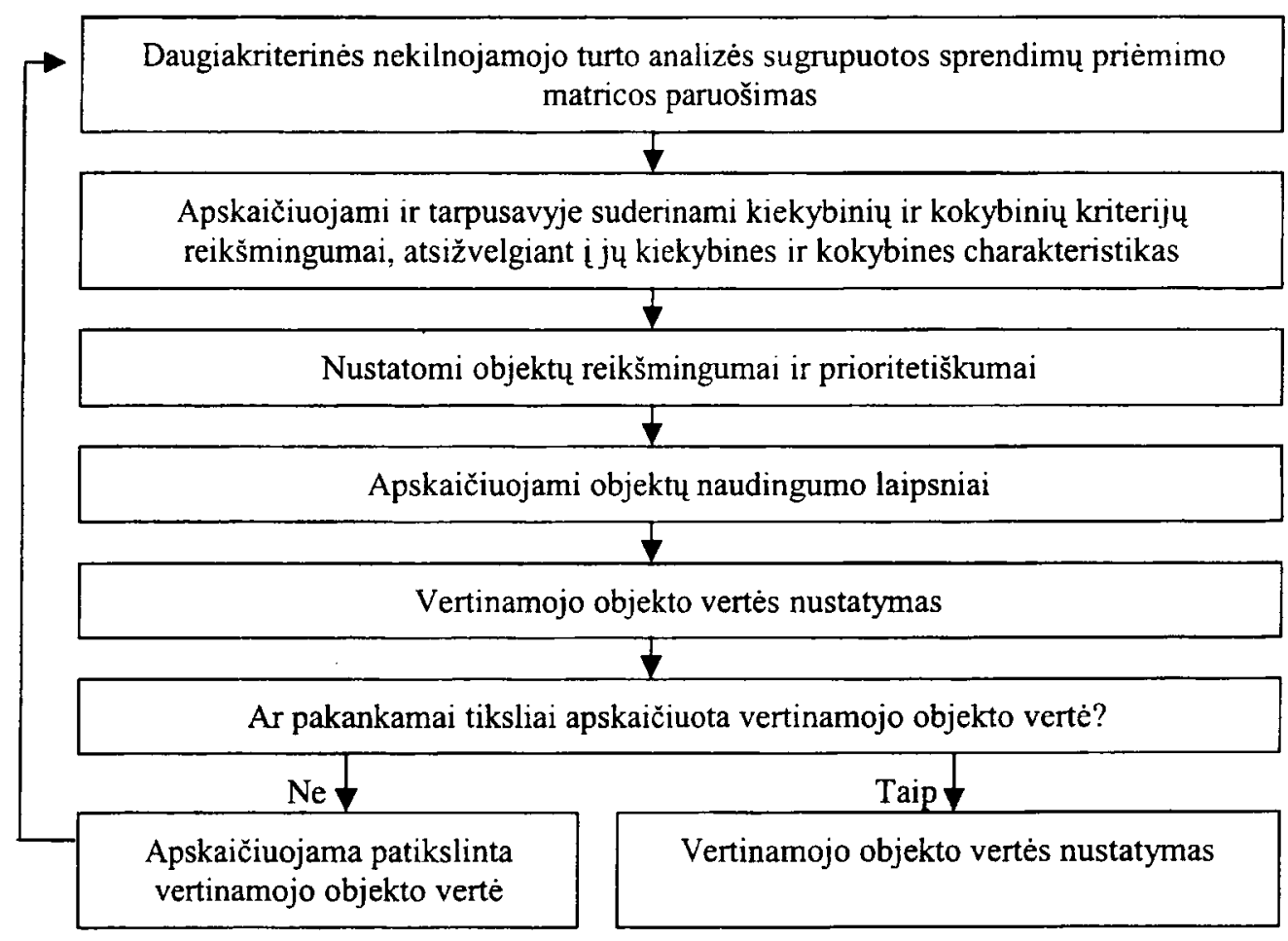

Daugiakriterinès nekilnojamojo turto analizès vertès nustatymo metodo blokinè schema

Block diagram of multiple criteria method for establishing value

7 etapas. Nustatomas objekto $a_{j}$ naudingumo procentas $N_{j}$ pagal formulę:

$$
N_{j}=\frac{Q_{j}}{Q_{\max }} \cdot 100 \% \text {. }
$$

8 etapas. Nustatomas visų varianty $a_{j}$ efektyvumo lygis $E_{x j}$. Jis rodo, kiek procentu geresnis (blogesnis) objektas $a_{x}$, palyginti su objektu $a_{j}$ :

$$
E_{x j}=N_{x}-N_{j}, \quad j=\overline{1, n} \text {. }
$$

9 etapas. Nustatomas objekto $a_{x}$ naudingumo procento $N_{j}$ vidutinis nuokrypis $k_{x}$ :

$$
k_{x}=\sum_{j=1}^{n} E_{x j}:(\mathrm{n}-1) .
$$

10 etapas. Jeigu 9 etape vertinamojo objekto naudingumo procento $N_{j}$ vidutinis nuokrypis $k_{x}$ neatitinka nelygybès:

$$
\left|k_{a x}\right|<1 \%,
$$

tai pereinama prie 11 etapo.
11 etapas. Vertinamojo objekto vertès $V_{x p}$ patikslinimas pagal formulę:

$$
V_{x p}=C_{x}\left(1+k_{x}: 100\right),
$$

$V_{x p}$ - patikslinta vertinamojo objekto verte; $C_{x}-$ patikslinta vertinamojo objekto vertė po n-ojo artèjimo; $k_{x}$ - vertinamojo objekto naudingumo procento $N_{j}$ vidutinis nuokrypis po n-ojo artejimo.

Vertinamojo objekto vertè tikslinama artejimo būdu, kol artejjimo ciklo vertinamojo objekto naudingumo procento vidutinis nuokrypis $k_{x}$ atitinka 9 nelygybę. Daugiakriterinio metodo 10 etape atitikus 9 nelygybe, eina 12 metodo etapas.

12 etapas. Vertinamojo objekto vertès $V_{Y}$ nustatymas pagal formule:

$$
V_{x}=C_{x}\left(1+k_{x}: 100\right),
$$

$V_{x}$ - vertinamojo objekto vertė; $C_{x}$ - patikslinta vertinamojo objekto verte po n-ojo artèjimo; $k_{x}$ - vertinamojo objekto naudingumo procento $N_{j}$ vidutinis nuokrypis. 


\section{Praktinis metodo taikymas}

Siekiant pademonstruoti pasiūlyto daugiakriterinès nekilnojamojo turto analizès vertès nustatymo metodo patikimuma, pateikiamas jo taikymo pavyzdys. $1999 \mathrm{~m}$. pavasari nekilnojamojo turto rinkoje buvo trys parduotuvès. Buvo nuspręsta nustatyti vienos iš jų rinkos vertę. Siekiant pademonstruoti metodo privalumus, lyginamieji objektai buvo parinkti iš skirtingu rinkos konjunktūrų, jos buvo įvertintos pagal rinkos konjunktūros kriterijus. Toliau yra pateiktas šių objektų koncepcinis aprašymas.

\subsection{Kiekybinis ir koncepcinis nagrinėjamų objektų aprašymas}

Pirmojo (vertinamojo) prekybinio objekto aprašymas. Rinkos konjunktüra ir vietoves aprašymas. Vertinamasis objektas yra Šalčininkų mieste. Šalčininkai yra apie $50 \mathrm{~km}$ i pietus nuo Vilniaus. Tai mažai gyventojų turintis miestas. Čia yra didžiausias Lietuvoje nedarbo lygis (14\%), dauguma miesto gyventoju važinejja dirbti ị Vilnių. Dèl savo nepatrauklumo šis miestas yra netinkamas turizmui. Vertinamasis objektas Mickevičiaus g. 13 esanti parduotuvè. Ji yra $1 \mathrm{~km}$ atstumu nutolusi nuo miesto centro, Mickevičiaus ir Vytauto gatviu sankirtoje. Atstumas nuo jos iki artimiausios autobusų stotelès $-1,5 \mathrm{~km}$. Šalia stovi gyvenamieji namai, $200 \mathrm{~m}$ atstumu yra vaikų darželis. Inžinerinė parduotuvès ịranga: vandentiekis, kanalizacija, elektra (miesto), šildymas krosnimi (kietasis kuras). Privažiuoti prie jos galima iš šiaurinès pusés - Vytauto gatve, iš rytinès - Mickevičiaus gatve. Dèl vangios nekilnojamojo turto cirkuliacijos (mažos paklausos) šiame mieste ji galima būtu priskirti prie investicijoms nepalankių miestu.

Prekybinio objekto kiekybès ir kokybès aprašymas. Vertinamasis objektas yra vieno aukšto pastatas, statytas 1985 m., kapitalinis remontas nebuvo atliktas. Bendrasis pastato plotas yra $131,49 \mathrm{~m}^{2}$, iš jo: prekybinis plotas $-60,30 \mathrm{~m}^{2}$, pirmojo aukšto tūris $-360 \mathrm{~m}^{3}$, rūsio nèra. Priešais pastatą yra ịrengta nedidelé automobilių stovejimo aikštelè. Tai atskiras pastatas, jo suplanavimas paprastas, lubų aukštis - 3.2 m. Yra antras išejjimas i kiemą. Pastato pamatai - betono, juostiniai, nuokrypių nuo horizontalès nèra. Sienos - plytu, iš lauko ir viduje tinkuotos, tinkas suskeldèjęs, prie pamatų ma- tyti drègmès žymių. Prie cokolio tinkas ištrupëjęs. Pertvaros - plytų, tinkuotos, dažytos, dažai nusilupe, kai kur tapetuotos, bet tapetai vietomis atsilupe nuo drègmés. Sanitarinio mazgo patalpa klijuota keraminemis plytelèmis. Stogas - šlaitinis, dengtas asbestcementiniais lakštais. Lubose matyti vandens nutekéjimo žymès. Perdangos - tinkuotos gelžbetoninès plokštès, matyti itrūkimai, kai kur tinkas nubyrejjęs, vietomis sudrèkęs. Grindys - betoninès, dengtos linoleumu, keraminémis plytelèmis. Linoleumas stipriai susidèvëjęs, reikia dengti naujai. Apie 30\% visų plytelių atšokusios. Langai - dvigubi, mediniai, dažyti, yra metalinès grotos. Langų rèmai išsikraipę, dažai nusilupę, apgadinti apkaustai, remuose matyti plyšiai. Durys - medinès, dažytos, dažai nusitrynę, rèmai išsikraipę, todèl jos nèra sandarios. Šalto ir karšto vandens irenginiai susidèveję, matyti nutekejjimo pèdsakai, korozijos žymès. Šalto vandens tinklas daug kartų remontuotas. Sanitarinis mazgas nesandarus, žymi tinklo korozija, irenginiai labai susidèvẻję. Sanitarinis mazgas daug kartų remontuotas. Pastate irengta vietinè šildymo sistema. Krosnis yra paprastų koklių, iš jų 10\% yra atšokusių. Pastato kondicionavimo sistema prasta. Yra signalizacija. Telefono linija - viena. Bendra pastato būklè bloga, būtinas kapitalinis remontas. Teritorija aplink pastatą nesutvarkyta, kiemo pusė apželdinta.

\section{Antrojo (lyginamojo) prekybinio objekto ap-} rašymas. Rinkos konjunktūra ir vietoves aprašymas. Lyginamasis objektas yra Vilniaus mieste, senamiestyje, Vilniaus gatveje Nr. 25. Tai prekybinès patalpos, esančios administracinio pastato pirmajame aukšte. Pastatas, kuriame isikūrusi parduotuve, turi architektürinę ir istorinę vertę, jis statytas XIX a., tačiau nuo to laiko ne kartą buvo keista jo paskirtis ir atlikta rekonstrukcija. Administracinis pastatas, kuriame yra vertinamosios prekybinès patalpos, yra $5 \mathrm{~km}$ atstumu nuo tarpmiestinių autobusu ir geležinkelio stoties. Iki artimiausios autobusu ir troleibusu stotelès yra $0,3 \mathrm{~km}$. Pastatas turi visą būtiną inžinerinę îrangą: miesto vandentiekị, fekalinę kanalizacija, centrini šildymą, elektrą. Privažiuoti prie prekybinio objekto galima iš senamiesčio centrinès dalies (Rotušès aikštès) - Vokiečių gatve, iš rytinès miesto dalies - Labdariụ gatve, iš šiaurinès - Vilniaus gatve. Šalia vertinamuju patalpu yra daug prestižinių parduotuvių, kavinių, restoranų bei biuru. Lyginamojo objekto lokalizacija labai palanki ir kitai veiklai, pvz., socialinei, komercinei bei administracinei. 
Prekybinio objekto kiekybès ir kokybès aprašymas. Lyginamasis objektas yra $1882 \mathrm{~m}$. statytame (rekonstruotame) name, kapitalinis remontas buvo atliktas $1979 \mathrm{~m}$. Patalpu bendrasis plotas - 165,53 $\mathrm{m}^{2}$, prekybinis - 94,44 $\mathrm{m}^{2}$. Patalpu tūris - $761 \mathrm{~m}^{3}$, rūsio tūris $278 \mathrm{~m}^{3}$. Asfaltuota automobilių stovẻjimo aikštelè yra kiemo pusèje, automobilius galima pastatyti ir prie pastato fasado. Iš viso aikštelèje yra penkios automobiliụ pastatymo vietos. Parduotuvès suplanavimas yra paprastas, ièjus pro duris patenkama $i$ tambūra ir iš jo $-i$ erdvią prekybos salę. Parduotuve turi du išejjimus, vienas iš jų - $\mathfrak{i}$ kiemo pusę. Pastato pamatai - akmenbetonio, juostiniai. Horizontaliosios pamatu sienų linijos taisyklingos, deformacijų nèra. Lauko ir vidaus sienos - plytú, tinkuotos. Fasadineje pusėje tinkas vietomis yra ištrupėjęs, matyti ịtrūkimų žymès. Pertvaros medinès, plytu, tinkuotos, tapetuotos, granito apdailos. Tapetai - nubluke, granito apdaila - apsitrynusi. Stogas - šlaitinis, $1979 \mathrm{~m}$. dengtas skarda. Perdangos medinès, tinkuotos, deformacijos žymių, pelèsių ir grybelio nèra. Lubų tinke yra nežymių ịtrūkimų. Prekybos salèje grindys yra granito plyteliu, kitose patalpose medinès, dengtos linoleumu, keraminèmis plytelèmis. Grindyse matomi nedideli plyšiai, plytelès kai kur atšokusios. Parduotuvès langai - dvigubi, mediniai, dažyti. Kiemo pusèje - plastikiniai langai, fasado pusèje - metalinès dažytos grotos. Langụ rèmuose matyti nežymūs dažų nusilupimai, itrūkimai rèmuose, nežymios deformacijos. Durys - medinès, dažytos, dvigubo stiklo, pastebimi nežymūs durų išsikraipymai, sumažèjęs sandarumas. Šalto ir karšto vandentiekio tinklas visiškai sandarus, matyti nežymus îrenginių susidèvèjimas. Fekalinès kanalizacijos tinkle nesandarumų nèra, irenginiai nežymiai nusidévèję, tačiau tai ịtakos ju funkcionavimui nedaro. Centrinio šildymo sistema funkcionuoja gerai, smulkūs nesandarumai matyti ties centrinio šildymo prietaisu čiaupais. Kondicionavimo sistema patalpose prasta. Yra vaizdo bei signalizacijos sistema, dvi ryšio linijos. Bendra patalpu būklè gera. Teritorija aplink lyginamaji objektą sutvarkyta, iš kiemo pusès ji apželdinta.

Trečiojo (lyginamojo) prekybinio objekto aprašymas. Rinkos konjunktūra ir vietovès aprašymas. Lyginamasis objektas yra Trakų miesto centre, Vytauto $g$. 42. Trakai yra respublikinès reikšmès kurortas, jis patenka i nacionalinio parko teritorija. Tai nedidelis miestas Vilniaus apskrityje, jame nèra pramonès imonių.
Vietiniai gyventojai verčiasi turizmu. Trakai neturi susisiekimo ir užterštumo problemu. Atstumas iki Vilniaus - $27 \mathrm{~km}$. Susisiekimas galimas elektriniu traukiniu, autobusais ir automobiliais. Rinkos požiūriu nekilnojamojo turto rinka mieste yra gan aktyvi ir, manoma, ateityje dar aktyvès. Lyginamasis objektas yra centrinejje miesto gatvèje. Autobusų ir geležinkelio stotys nuo jo yra $1 \mathrm{~km}$ atstumu. Šalia parduotuvès $0,5 \mathrm{~km}$ atstumu nèra jokios kitos parduotuvès. Lyginamojo objekto vietos padètis yra gera klientụ atžvilgiu. Jis turi visas miesto komunikacijas: vandentieki, fekalinę ir lietaus kanalizacijas, centrinį šildymą, elektrą. Privažiavimas prie pastato iš vakarinès jo pusès - Vytauto gatve.

Prekvbinio objekto kiekybès ir kokybès aprašymas. Lyginamasis objektas yra vieno aukšto atskiras pastatas, pastatytas $1957 \mathrm{~m}$., kapitalinis remontas nedarytas. Objekto bendrasis plotas - 203,43 $\mathrm{m}^{2}$, rūsio plotas $94,78 \mathrm{~m}^{2}$. Pirmojo aukšto patalpu tūris $-864 \mathrm{~m}^{3}$, rūsio - $406 \mathrm{~m}^{3}$. Prekybinis plotas $-79,64 \mathrm{~m}^{2}$. Šalia parduotuvès yra asfaltuota 15 vietu automobilių stovèjimo aikštelè. Dviračiams skirtos aikštelès nèra. Parduotuvès suplanavimas yra gan paprastas: iejus pro duris iš fasado pusés patenkama i tambūrą, iš jo - tiesiai i prekybos salę. Patalpų aukštis yra $3,4 \mathrm{~m}$. Parduotuvè turi du papildomus išejjimus - vieną i kiemo pusę, kitą - i pastato šonini fasadą. Objekto pamatai - betono, juostiniai, nuokrypių nuo horizontalès nèra, cokolis - tinkuotas, tinkas ištrupejjęs. Sienos - plytu, viduje ir lauko pusèse - tinkuotos, išorejje matyti itrūkimų žymès, cokolio tinkas - ištrupejjęs ir sudrèkęs. Pertvaros - plytụ, tinkuotos, dažytos ir tapetuotos, dažai vietomis nusilupę. Sanitarinio mazgo patalpa - klijuota keraminèmis plytelèmis. Stogas - šlaitinis, dengtas asbestcementiniais lakštais ant mediniu konstrukciju. Stogas nesandarus, lubose matyti vandens nutekèjimo žymės. Jo perdangos - tinkuotos gelžbetoninès plokštès, kai kuriose vietose matyti deformacijos. Lubų tinke matyti ịtrükimų, vandens nutekejjimo žymių. Grindys - betoninès, dengtos linoleumu, keraminèmis plytelèmis. Linoleumas vietomis išplyšęs, labai nusitrynęs. Apie $20 \%$ visụ keraminiu plytelių yra atšokusios. Langai - dvigubi, mediniai, dažyti, yra metalinès dažytos grotos. Langụ rèmai - išsikraipę, rèmuose matyti plyšiai, itrūkimai, apkaustai apgadinti, dažai nusilupę. Durys - medinès, dažytos, matyti žymios deformacijos, todèl sumažèjęs ju sandarumas. Kai kurias šalto ir karšto vandens 
irrenginiu detales reikia keisti. Kanalizacijos tinkle yra nesandarumu, irenginiai nusidèveję. Centrinès miesto šildymo sistemos tinkle yra nesandarumų, reikia nesudètingo remonto. Kondicionavimo sistema prasta. Nèra vaizdo sistemos, tačiau yra signalizacija. Yra du telefonai. Bendra prekybinio objekto būklè - patenkinama, reikia remonto. Teritorija aplink pastatą sutvarkyta, prie priekinio fasado - apželdinta.

\subsection{Tyrimo eiga ir gautu rezultatų aptarimas}

Pirmajame artẻjimo cikle vertinamojo objekto pradinè vertè buvo prilyginta lyginamuju objektu pardavimo kainų vidurkiui, t. y. $560000 \mathrm{Lt}$ (2 lent.).

Sudarius kriterijų sistemą ir nustačius jụ reikšmes bei reikšmingumus, buvo parengta sugrupuota sprendimų prièmimo matrica (2 lent.). Remiantis šia matrica, pagal (1) formulę buvo apskaičiuoti kriterijų reikšmingumai:

$$
\begin{aligned}
d_{11} & =560,00 \cdot 1,00 /(560,00+600,00+520,00)= \\
& =0,3333 ; \\
d_{12} & =600,00 \cdot 1,00 /(560,00+600,00+520,00)= \\
& =0,3571 ; \\
d_{13} & =520,00 \cdot 1,00 /(560,00+600,00+520,00)= \\
& =0,3095 ; \\
d_{21} & =0,09 \cdot 0,75 /(0,09+4,90+4,10)=0,0074 ; \\
d_{22} & =4,90 \cdot 0,75 /(0,09+4,90+4,10)=0,4043 ; \\
d_{23} & =4,10 \cdot 0,75 /(0,09+4,90+4,10)=0,3383 ; \\
d_{31} & =0,40 \cdot 0,0081 /(0,40+0,20+0,30)= \\
& =0,0036 ; \\
d_{32} & =0,20 \cdot 0,0081 /(0,40+0,20+0,30)= \\
& =0,0018 ; \\
d_{33} & =0,30 \cdot 0,0081 /(0,40+0,20+0,30)= \\
& =0,0027 .
\end{aligned}
$$

Kiekvieno kriterijaus gautụ bedimensiu ivertintu reikšmiụ $d_{i j}$ suma visada lygi šio kriterijaus reikšmingumui, pavyzdžiui, rinkos konjunktūros kriterijus apskaičiuojamas pagal (2) formulę:

$$
q_{2}=0,0074+0,4043+0,3383=0,7500 .
$$

Vertinant buvo nustatyta, kad didžiausią itaką tiriamo nekilnojamojo turto (prekybinio objekto) esamo naudojimo rinkos vertei turi rinkos konjunktūra $\left(q_{2}=0,75\right)$ ir žymiai mažesnę - vietos padètis susisiekimo atžvilgiu, klientu patogumo atžvilgiu, vietovès prestižas ir vietos padetis apskrities centro atžvilgiu $\left(q_{21}=0,0637, q_{22}=0,0363, q_{27}=0,0286, q_{23}=0,0194\right)$.
Vèliau buvo apskaičiuotos lyginamuosius ir vertinamaji objektus apibūdinančiu minimizuojančių $S_{-j}$ ir maksimizuojančių $S_{+j}$ ivertintụ normalizuotų rodiklių sumos pagal (3) formulę:

$$
\begin{aligned}
& S_{-1}=0,3333+0,0030=0,3363 ; \\
& S_{-1}=0,0253 ; \\
& S_{-2}=0,3602 ; S_{-2}=0,5476 ; \\
& S_{-3}=0,3126 ; S_{-3}=0,4179 .
\end{aligned}
$$

Šiuo atveju $S_{+j}$ ir $S_{-j}$ dydžiai išreiškia lyginamaisiais objektais pasiektu tikslu lygi. Bet kuriuo atveju visų lyginamuju objektu pliusu $S_{+j}$ ir minusų $S_{-j}$ sumos visada yra lygios atitinkamai visoms maksimizuojančiu ir minimizuojančių kriterijų reikšmingumų sumoms pagal (4) formulę:

$$
\begin{aligned}
S_{-} & =0,3333+0,3571+0,3095+0,0030+ \\
& +0,0030+0,0030=1,0089 ; \\
S_{+} & =0,9909 .
\end{aligned}
$$

Vèliau, remiantis (5) formule, nustatytas kiekvieno lyginamojo ir vertinamojo objektu santykinis reikšmingumas:

$$
\begin{aligned}
\mathrm{Q}_{1} & =0,025342+0,312557 \cdot(0,336366+ \\
& +0,360176+0,312557) / 0,336366 \cdot \\
& \cdot(0,312557 / 0,336366+0,312557 / 0,360176+ \\
& +0,312557 / 0,312557)=0,3612 ; \\
Q_{2} & =0,8571 ; Q_{3}=0,7817 .
\end{aligned}
$$

Pirmajame artejimo cikle, remiantis (6) formule, kaip naudingiausias pagal naudojimo paskirti buvo ivertintas lyginamasis objektas, esantis Vilniuje: $N_{2}=100 \%$, antrasis pagal naudingumą - lyginamasis objektas, esantis Trakuose: $N_{3}=91,19 \%$, ir trečiasis - vertinamasis objektas, esantis Šalčininkuose: $N_{1}=42,14 \%$ ( 2 lent.). Vèliau buvo nustatytas lyginamuju ir vertinamojo objektu efektyvumo lygis $E_{x j}$ ((7) formule). Jis rodo, kiek procentu geresnis (blogesnis) vertinamasis objektas, palyginti su lyginamaisiais tarpusavyje. Pavyzdžiui:

$$
\begin{aligned}
& E_{11}=42,14 \%-42,14 \%=0,00 \% ; \\
& E_{12}=42,14 \%-100,00 \%=-57,86 \% ; \\
& E_{13}=42,14 \%-91,19 \%=-49,05 \% ; \\
& E_{21}=57,86 \% ; E_{22}=0,00 \% ; E_{23}=8,81 \% ; \\
& E_{31}=49,05 \% ; E_{32}=-8,81 \% ; E_{33}=0,00 \% .
\end{aligned}
$$

Vèliau, remiantis (8) formule, buvo apskaičiuotas vertinamojo objekto naudingumo lygio vidutinis nuokrypis $k_{x}$, nuo kurio ir priklauso, ar kitu etapu iškart 
2 lentelè. Sugrupuota sprendimu priėmimo matrica parduotuvių daugiakriterinei analizei atlikti

Table 2. Intitial data for multiple criteria valuation

\begin{tabular}{|c|c|c|c|c|c|c|c|}
\hline \multirow{2}{*}{$\begin{array}{l}\text { Krite- } \\
\text { rijaus } \\
\mathrm{Nr} .\end{array}$} & \multirow{2}{*}{ Nagrinejjamas kriterijus } & \multirow[t]{2}{*}{$*$} & \multirow{2}{*}{$\begin{array}{c}\text { Kriterijaus } \\
\text { matavimo } \\
\text { vienetas }\end{array}$} & \multirow{2}{*}{$\begin{array}{c}\text { Kriterijaus } \\
\text { reikšmin- } \\
\text { gumas }\end{array}$} & $\begin{array}{c}\text { Vertinamasis } \\
\text { objektas }\end{array}$ & $\begin{array}{c}\text { Lyginamasis } \\
\text { objektas Nr. } 1\end{array}$ & $\begin{array}{c}\text { Lyginamasis } \\
\text { objektas Nr. } 2\end{array}$ \\
\hline & & & & & Šalčininkai & Vilnius & Trakai \\
\hline 1 & Pardavimo kaina & - & $1000 \mathrm{Lt}$ & 1,0000 & 560,0000 & 600,0000 & 520,0000 \\
\hline 2 & Rinkos konjunktūra & + & balai & 0,7500 & 0,0900 & 4,9000 & 4,1000 \\
\hline 3 & $\begin{array}{l}\text { Pastato būklè (amžius, kapitalinis } \\
\text { remontas) }\end{array}$ & + & balai & 0,0081 & 0,4000 & 0,2000 & 0,3000 \\
\hline 4 & Pastato ir patalpu prioritetas & + & balai & 0,0003 & 1,0000 & 0,8000 & 1,0000 \\
\hline 5 & Pastato (patalpų) bendrasis plotas & + & $\mathrm{m}^{2}$ & 0,0052 & 131,4900 & 165,5300 & 203,4300 \\
\hline 6 & Prekybinis plotas & + & $\mathrm{m}^{2}$ & 0,0066 & 60,3000 & 94,4400 & 79,6400 \\
\hline 7 & $\begin{array}{l}\text { Stovèjimo aikštelè (automobilių } \\
\text { skaičius) }\end{array}$ & + & vnt. & 0,0101 & 3,0000 & 5,0000 & 15,0000 \\
\hline 8 & Statybos būdas & + & balai & 0,0011 & 1,0000 & 0,8000 & 1,0000 \\
\hline 9 & Patalpų suplanavimas & + & balai & 0,0006 & 0,2000 & 0,8000 & 0,8000 \\
\hline 10 & Konstrukcijos, jụ būklè & + & balai & 0,0139 & 0,2000 & 0,9000 & 0,3000 \\
\hline 11 & Vidaus apdaila & + & balai & 0,0032 & 0,0100 & 1,0000 & 0,2000 \\
\hline 12 & Išorès apdaila & + & balai & 0,0035 & 0,0100 & 0,8000 & 0,1000 \\
\hline 13 & Rūsys & + & balai & 0,0015 & 0,0000 & 1,0000 & 0,8000 \\
\hline 14 & Šilumos izoliacija & + & balai & 0,0124 & 0,1000 & 1,0000 & 0,5000 \\
\hline 15 & Šildymo sistema & + & balai & 0,0107 & 0,1000 & 0,9000 & 0,7000 \\
\hline 16 & Kondicionavimo sistema & + & balai & 0,0013 & 0,1000 & 0,9000 & 0,1000 \\
\hline 17 & Signalizacijos sistema & + & balai & 0,0003 & 0,1000 & 1,0000 & 0,7000 \\
\hline 18 & Vaizdo stebėjimo sistema & + & balai & 0,0002 & 0,0000 & 1,0000 & 0,0000 \\
\hline 19 & Telefonas & + & balai & 0,0002 & 0,3000 & 1,0000 & 1,0000 \\
\hline 20 & $\begin{array}{l}\text { Pagalbinių statiniu (sandèlių, rampu) } \\
\text { kompleksinis ịvertinimas }\end{array}$ & + & balai & 0,0006 & 0,1000 & 0,1000 & 0,1000 \\
\hline 21 & Susisiekimo galimybès & + & balai & 0,0637 & 0,0100 & 1,0000 & 0,8000 \\
\hline 22 & Patogumas klientụ atžvilgiu & + & balai & 0,0363 & 0,1000 & 1,0000 & 0,7000 \\
\hline 23 & Vietos padètis miesto centro atžvilgiu & + & balai & 0,0194 & 0,0000 & 1,0000 & 0,0000 \\
\hline 24 & $\begin{array}{l}\text { Statybos ir rekonstrukcijos } \\
\text { apribojimai }\end{array}$ & + & balai & 0,0091 & 1,0000 & 1,0000 & 1,0000 \\
\hline 25 & $\begin{array}{l}\text { Galimybė panaudoti pastata } \\
\text { (patalpas) kitai veiklai }\end{array}$ & - & balai & 0,0092 & 0,3000 & 1,0000 & 0,5000 \\
\hline 26 & Pastato patrauklumas & + & balai & 0,0023 & 0,1000 & 0,7000 & 0,2000 \\
\hline 27 & Vietovès prestižas & + & balai & 0,0286 & 0,2100 & 2,0000 & 1,0000 \\
\hline 28 & Teritorijos sutvarkymas & + & balai & 0,0016 & 0,2000 & 0,9000 & 0,7000 \\
\hline
\end{tabular}

* Ženklas $+(-)$ rodo, kad didesnè (mažesnè) kriterijaus reikšmé labiau atitinka suinteresuotos grupès reikalavimus. 
bus nustatoma vertinamojo obj : 10 esamo naudojimo rinkos vertè, ar bus tik patikslinia pradinè vertẻ ir kartojamas artejimo ciklas. Po pirmojo artejimo ciklo vertinamojo objekto naudingumo lygio vidutinis nuokrypis $k_{x}$ neatitiko (9) nelygybės. Gautas toks rezultatas:

$$
k_{a x}=|-53,46|>1 \text {. }
$$

Tuomet, remiantis (10) formule, buvo patikslinta vertinamojo objekto vertè:

$$
V_{1}=560000(1-53,46 / 100)=260652 \mathrm{Lt} \text {. }
$$

Patikslinus vertinamojo objekto vertę pagal metodo blokinę schema, toliau eina metodo artejjimo ciklas.

Kaip matome iš 2 lentelès, pirmajame artẻjimo cikle naudingiausias pagal naudojimo paskirti yra lyginamasis objektas, esantis Vilniuje $\left(N_{2}=100 \%\right)$, antrasis pagal naudingumą - lyginamasis objektas, esantis Trakuose $\left(N_{3}=91,19 \%\right)$, ir trečiasis - vertinamasis objektas, esantis Šalčininkuose $\left(N_{1}=42,14 \%\right)$. Kaip matome iš apskaičiuotų objektų naudingumo laipsnių, vertinamojo prekybinio objekto Šalčininkuose pradinè vertẻ $(\mathrm{X}=560000 \mathrm{Lt})$ yra per didelè, dèl to šis objektas nèra vienodai konkurencingas rinkoje, palyginti su objektais Trakuose ir Vilniuje, kompleksiškai Ł̇vertinus ju teigiamas ir neigiamas savybes. Tą patị faktą patvirtina ir nelygybe $k_{a x}=|-53,46|>1$. Remiantis šia nelygybe buvo nustatyta, kad dar nepakankamai tiksliai apskaičiuota vertinamojo objekto Šalčininkuose vertè.

Todèl, remiantis vertinamojo nekilnojamojo turto objekto vertès skaičiavimo blokine schema, pateikta 2 paveiksle, skaičiavimų ciklai buvo tęsiami tol, kol buvo patenkinta nelygybé $\left|k_{a x}\right|<1 \%$.
Šių skaičiavimų ciklų rezultatai: vertinamojo objekto Šalcininkuose patikslintos vertès kitimas ir esamo naudojimo rinkos vertès nustatymas - pateikti 3 lentelèje.

Kaip matome, nelygybe் $\left|k_{a x}\right|<1 \%$ pirmuosius 6 ciklus buvo netenkinama. Todèl 7 kartus patikslinta vertinamojo objekto verté $V_{x p}$ (atitinkamai $260652 \mathrm{Lt}$, 199090 Lt, 176796 Lt, 166970 Lt, 162257 Lt, $159904 \mathrm{Lt}$ ) buvo irašoma i nekilnojamojo turto objektụ daugiakriterinès analizès sprendimu prièmimo matricą (2 lent.). Visi skaičiavimai pagal (1)-(9) formules buvo kartojami tol, kol septintajame cikle buvo patenkinta nelygybè $\left|k_{a x}\right|<1 \%$.

Kaip matome iš 3 lentelès, kiekviename kitame artèjimo cikle vis tiksliau buvo apskaičiuojama vertinamojo objekto verte. Paskutiniame - septintajame artėjimo cikle vertinamojo objekto naudingumas lyginamuju objektų atžvilgiu nustatytas toks: $N_{1}=92,50 \%$, lyginamojo objekto, esančio Traku rajone: $N_{3}=86,50 \%$, o kito lyginamojo objekto, esančio Vilniaus mieste, liko nepakitęs per visus artejjimo ciklus: $N_{2}=100 \%$. Apskaičiuoti objektu naudingumo laipsniai rodo, kad vertinamasis objektas $6 \%$ yra naudingesnis už lyginamaji objekta, esantị Trakų rajone, ir 7,5\% mažiau naudingas už lyginamaji objekta, esantị Vilniuje. Šie skaičiai taip pat rodo, i kurị objektą labiau apsimoka investuoti pinigus.

Kaip jau buvo minèta, vertinamasis objektas buvo parduotas atviroje rinkoje, o jo vertè nustatyta nauju daugiakriterinès analizès vertès nustatymo metodu, siekiant patikrinti metodo patikimumą. Vertinamoji parduotuvè, esanti Šalčininkuose, buvo parduota už 180000 Lt. Siūlomu daugiakriterinès analizès metodu ji ịvertinta

3 lentelè. Vertinamojo objekto naudingumo lygio vidutinio nuokrypio ir patikslintos vertès kitimas bei esamo naudojimo rinkos vertès nustatymas

Table 3. Determining the average deviation of utility and market value of an object valuated; variation of corrected value

\begin{tabular}{|c|c|c|c|}
\hline $\begin{array}{c}\text { Artèjimo } \\
\text { ciklas }\end{array}$ & $\begin{array}{c}\text { Vertinamojo objekto } \\
\text { patikslinta verte }\end{array}$ & Vertės paklaida & Esamo naudojimo rinkos vertè \\
\hline 1 & 560000,00 & $-53,46 \%$ & \\
2 & 260651,74 & $-23,62 \%$ & \\
3 & 199090,24 & $-11,20 \%$ & \\
4 & 176795,78 & $-5,56 \%$ & \\
5 & 166969,93 & $-2,82 \%$ & \\
6 & 162257,11 & $-1,45 \%$ & \\
7 & 159904,00 & $-0,75 \%$ & $159904 \times(1-0,75: 100)=\mathbf{1 5 8} \mathbf{7 0 5 , 4 0}$ \\
\hline
\end{tabular}


beveik $159000 \mathrm{Lt}$, ir tai sudaro $87 \%$ pirkimo-pardavimo kainos. Tarptautinèje mokslinèje nekilnojamojo turto vertinimo literatūroje teigiama, kad rinkos duomenys, t. y. pirkimo-pardavimo kainos, viršijančios $\pm 30 \%$ ribą nuo kitu tokios pat paskirties nekilnojamojo turto kainu, yra atmetami kaip nepatikimi $[8,9,10]$. Tyrimo atveju nauju metodu gauta parduotuvès esamo naudojimo rinkos verte skiriasi tik $13 \%$ nuo jos pirkimo-pardavimo kainos, todèl galima teigti, kad šis siūlomas daugiakriterinès analizès vertès nustatymo metodas yra patikimas ir tinkamas taikyti vertinant nekilnojamaji turtą.

\section{Išvados}

1. Daugiakriterinès nekilnojamojo turto analizès vertès nustatymo metodas paremtas rinkos ir nekilnojamojo turto analize bei nekilnojamojo turto rinkos vertę veikiančių kokybiniu, kiekybiniu bei rinkos konjunktūros kriteriju nustatymu ir jivertinimu. Todèl šis metodas leidžia kompleksiškai vertinti ne tik lyginamuju turto objektų kokybinius, bet ir kiekybinius bei su tais objektais susijusių rinkų konjunktūrų skirtumus.

2. Daugiakriterinès nekilnojamojo turto analizès vertès nustatymo metodo patikimumas patikrintas šiame straipsnyje pateiktu uždaviniu. Tyrimo rezultatai rodo, kad esamo naudojimo rinkos vertè, apskaičiuota siūlomu metodu, skiriasi nuo faktinés vertinamojo objekto pirkimo-pardavimo kainos tik 13\%. Tarptautinejje mokslinèje nekilnojamojo turto vertinimo literatūroje teigiama, kad rinkos duomenys, t. y. pirkimo-pardavimo kainos, viršijančios tik $\pm 30 \%$ ribą nuo kitų tokios pat paskirties turto vidutiniu kainu, yra atmetami kaip nepatikimi. Todèl galima teigti, kad straipsnyje pateiktas daugiakriterinès nekilnojamojo turto analizès vertès nustatymo metodas yra patikimas.

3. Šiuo metodu gali naudotis visos nekilnojamuoju turtu suinteresuotos grupès - rinkos dalyviai: pirkèjai, pardavejai, investuotojai, vertintojai ir kt., - siekiančios patenkinti savo poreikius ir tikslus.

\section{Literatūra}

1. Bundesministerium für Raumordnung, Bauwesen und Städtebau. Funktionsweise städtischer Bodenmärkte in Mitgliedstaaten der europäischen Gemeinschaft - ein Systemvergleich. Druck Lottmann, Pulheim, Veröffentlicht: 11/1993, $327 \mathrm{~S}$.
2. K. Gablenz. Verkehrswertermittlung von landwirschaftlichen Grundstücken. 1 Auflage. Verlag Bundesanzeiger, Köln, 1998. 545 S.

3. K. P. Keunecke. Immobilien Bewertung - Entscheidungsorientierte Ansaetze bei der grundstuecks - und Gebeaudebewertung. Verlag Springer, Berlin, Heidelberg, 1994. $172 \mathrm{~S}$.

4. E. K. Zavadskas, A. Kaklauskas. Pastatų sistemotechninis ivertinimas. Vilnius: Technika, 1996. 280 p.

5. E. K. Zavadskas, A. Kaklauskas, E. Bejder. Multiple criteria analysis of projects. Aalborg: Aalborg Universitetscenter, 1992. $93 \mathrm{p}$.

6. E. K. Zavadskas, A. Kaklauskas, E. Bejder, T. Motekūnas. Pastato statybos ir eksploatacijos daugiatikslè selektonovacija. Vilnius: Technika, 1992. 82 p.

7. E. K. Zavadskas, L. Simanauskas, A. Kaklauskas. Sprendimu paramos sistemos statyboje. Vilnius: Technika, 1998. 235 p.

8. W. Kleiber, J. Simon, G. Weyers. Verkehrswertermittlung von Grundstücken. 3 Auflage. Verlag Bundesanzeiger, Köln, 1998. $2358 \mathrm{~S}$.

9. H. O. Sprengnetter. Handbuch zur Ermittlung von Grundstückswerten und für sonstige Wertermittlungen Band IV- Theoretische und rechtliche Grundlagen Anleitungen für die Praxis. Teil 2, 3. 6.

10. J. Simon, K. G. Cors, M. Troll. Handbuch der Grundstückswertermittlung. 3 Auflage. Verlag Vahlen, München, 1992. $961 \mathrm{~S}$.

Iteikta 20001004

\section{APPLICATION OF METHOD OF MULTIPLE CRITE-} RIA ANALYSIS FOR ESTABLISHING VALUE

\section{Malienė, A. Kaklauskas, E. K. Zavadskas}

\section{Summary}

Multiple criteria analysis presented in this paper for property valuation may be used to the advantage of various interested parties. The representatives of various parties including appraisers. buyers, sellers and investors may use it for their particular purposes:

- appraiser may apply this method to real estate value analysis for determining the market, use and other values of real estate being mortgaged. ensured. privatised. divided or nationalised;

- investor may rely on it for more efficient use of this property;

- buyer may use it for choosing property which would satisfy his personal needs to the best advantage;

- seller can use it for determining the market price of his property that would ensure its competitive ability on the market.

To satisfy all the needs described, multiple criteria valuation method presented in the paper may be successfully applied. To show its efficiency, the solution of a sample problem representing a real case is provided. 
Vida MALIENĖ. PhD student. Dept of Building Technology and Management. Vilnius Gediminas Technical University, Saulètekio al. 11, LT-2040 Vilnius, Lithuania. E-mail: Vida.Maliene@ist.vtu.lt

A graduate of Vilnius Gediminas Technical University. MSc (1996). Research visits to Bonn Friedrich-Wilhelm University (Germany, 1997/1998), Leipzig Higher School of Technology, Economics and Culture (Germany, 1998). Research interests: real estate valuation and management, land survey.

Artūras KAKLAUSKAS. Doctor Habil, Professor. Dept of Building Technology and Management. Vilnius Gediminas Technical University, Sauletekio al. 11, LT-2040 Vilnius, Lithuania. E-mail: property@st.vtu.lt

A graduate of Vilnius Civil Engineering Institute (since 1990 Vilnius Technical University) (1984, civil engineer). PhD (1990). Research visits to Aalborg University (Denmark, 1991), University of Glamorgan (UK, 1993/1995). Author and coauthor of 4 monographs and more than 50 papers. Research interests: multiple criteria decision-making, expert systems, total quality management, computer-aided design.
Edmundas Kazimieras ZAVADSKAS. Doctor Habil, Professor. Rector of Vilnius Gediminas Technical University. Member of Lithuanian Academy of Sciences. Member of Ukrainian Academy of Technological Cybernetics. Vilnius Gediminas Technical University, Saulètekio al. 11, LT-2040 Vilnius, Lithuania. E-mail: Rector@adm.vtu.lt

In $1973 \mathrm{PhD}$ (building structures). Professor at the Dept of Building Technology and Management. In 1987 Dr Habil (building technology and management). Research visits to Moscow Civil Engineering Institute, Leipzig and Aachen Technical Universities. He maintains close academic links with the universities of Aalborg (Denmark). Salford and Glamorgan (Great Britain), Poznan University of Technology (Poland), Leipzig Higher School of Technology, Economics and Culture (Germany) and Aachen Technical University (Germany). Member of international organisations. Member of steering and programme committees of many international conferences. Member of editorial boards of some research journals. Author of monographs in Lithuanian, English, German and Russian. Research interests: building technology and management, decision-making theory, automation in design, expert systems. 